\title{
АНТРОПОЛОГИЈА НА МУЛТИКУЛТУРАЛИЗМОТ: ТЕОРИЈА И ПРАКТИКА
}

Апстракт: Базичната тема на рефератот е мултикултурноста како теориско антрополошко прашање, на кое последниве децении му се посветува особено внимание од страна на општествените и од хуманистички науки.

Рефератот се занимава со развојот на основните постулати на мултикултурноста, која, како спроведена неколку децениска акција, во својот развој доживеа радикални промени. Интересот особено е предизвикан поради јавните искази од самиот европски врв за неуспешноста на овој концепт, на неуспешниот повеќегодишен обид за интегрирање, пред сѐ, на имигрантските етнички заедници во веќе постојните либерални демократии.

Начините на кои една етничка заедница со културни карактеристики, различни од оние во државите, каде што настојува да се инкорпорира, можат да се манифестираат преку сегрегација, асимилација, постепена акултурација, но и преку признавање и почитување на идентитетските посебности на разните етнички и културни заедници.

За мултикултурализмот најчесто се зборува како за синоним на културниот плурализам, анализиран преку постоењето на мултикултурната реалност, но и за мултикултурализмот како теорија и одговор на таа реалност, кој долги години создава(ше) механизми, преку кои се обидуваше да го направи успешен овој проект.

Клучни зборови: мултикултура, мултикултурност, културен идентитет, културни различности, мултикултурно општество граѓанство.

Имајќи го предвид културниот плурализам, манифестиран низ разни форми, мултинационалните европски држави познаваат различни типови на културна разновидност. Разновидноста може да биде резултат на вклучување на претходни културни вредности, релативно блиски и сродни, кои се инкорпорираат во една поширока држава, како што беше случај со Социјалистичка Федеративна Република Југославија, од една страна и денешните европски држави, најчесто членки на Европската Унија, каде што денешната мултикултуралност најпрво е резултат на масовните доселувања во последните две децении, на население од поинакви културни простори во европска средина. Поради овој факт, разбирањето и практикувањето на мултикултурноста не е насекаде исто. Ниту механизмите преку кои тоа се практикува не се исти. За подобро разбирање на манифестната мултикултурност е потребно да се познаваат одредени компоненти, кои го сочинуваат или влијаат врз појавата и справувањето со мултикултурализмот како процес. Тука, пред сѐ, влегуваат познавањето на улогата и значењето на: етничкиот, националниот, религискиот и културниот идентитет, улогата на културата како посебност при создавање на културните различности 
(диверзитети), а особено при креирањето на културните политики и создавањето на мултикултурното општество, потоа глобализацијата, миграциите.

Дискурсот за етничкиот идентитет, како културна категорија, претставува исклучително сложено и комплексно прашање важно при создавање на начините на кои би се формирале културните политики за другиот, различниот во општеството. Да се идентификува некој или нешто значи да се препознае нештото, да се одреди, да се прифати, да се усвои, да се дефинира (не)истоветноста на културните, духовните, религиските и психолошките карактеристики на ниво на индивидуалното (човек, индивидуа, личност) или на колективното (група, заедница).

Во основа, етничкиот идентитет би можел да се дефинира како групен идентитет, кого поединецот го стекнува како член на етничка или национална група (Павловић, 1998, 83) или како „организација на ментална структура на когнитивни (сознајни) и афективни (сродни) карактеристики, кои ги претставуваат погледите и сфаќањата на поединецот за самиот себе како за различно суштество во согласност со себе, а засебно од другите, со разумен степен на кохеренција во однесувањето, потребите, мотивациите и интересите“" (Golubović, 1997, 136, 137). Ако ова е општо прифатено, тогаш е неспорна потребата од различен пристап кон засебните други идентитети. Истовремено, дефинирајќк ја нацијата како замислена заедница, создадена како културна творба, правејќ јасна дистинкција меѓу нацијата како етничка заедница и нацијата како државна и политичка заедница, други автори зборуваат за политичкиот и за културниот аспект при дефинирањето на националниот идентитет, особено во мигрантските заедници. Културниот аспект може да биде манифестиран преку заеднички елементи, како што е јазикот, но истовремено и преку: историската поврзаност, религијата, обичаите. Уште еден елемент, кога станува збор за културниот идентитет, не треба да се заборави: што станува со културниот идентитет на дијаспората од конкретна етничка заедница? Од овој аспект, гледано во современи услови, дали Македонците или другите балкански народи, кои живеат во други држави, особено оние од третата или четвратата генерација, кои не го зборуваат македонскиот јазик, имаат чувство на припадност кон македонската заедница? Културниот идентитет на еден етнос во матичната држава се разликува од културниот идентитет на истиот етнос кога тој живее во нематична средина. Културите на дијаспората, сфатени и прифатени како „и тука/и таму“ („ни тука/ни таму“) се предмет на посебна анализа.

Ако од денешна временска дистанција се дискутира за теориските рамки во кои треба да се анализира националниот (етнички) идентитет, не може да се апстрахира поврзаноста на политичката и економската моќ со националниот идентитет, делумно и поради самиот факт дека една од функциите на националниот идентитет е токму политичката (таа ги поставува границите меѓу групите, ги потенцира заедничките интереси). Според ова, е јасно дека не можат да се генерализираат ставките, кои би го дефинирале секогаш националниот идентитет. Во некои случаи, некој од параметрите е важен на припадниците на одредена нација, а некој е помалку важен. Нема 
одредници кои би биле еднакво важни при секое дефинирање на конкретен национален идентитет, што доведува до фактот дека за секоја анализа на националниот идентитет предвид треба да бидат земени: историските, политичките, економските збиднувања на конкретна заедница во даден простор и во дадено време. Сите овие фактори го прават идентитетот повеќеслоен без меѓусебно исклучување (Мирчевска, 2007, 35).

Една друга категорија, која особено ја потенцира Барт, го допира односот на релација ние-тие или јас-тој што, од своја страна, доведува до зацврстување на етничкиот/религискиот/културниот идентитет на групата или поединецот. Тоа чувство на посебност всушност ја дефинира разликата меѓу народите/заедниците, кое истовремено треба да е присутно и кај „другиот“ односно посебноста да биде забележана. Колку реално е поразлична државата по сите основи, од онаа од која некој доаѓ, толку е потешко да се привикне на новото општество во кое живее. Личниот и групниот идентитет се конструира во процесот на персоналната и на групната интеракција и е под влијание на општествените и на културните промени од кои поединецот или групата изведува систем на идентификација, на чија основа се пронаоѓаат во својата околина. Една генерација формативно дејствува на другата, по пат на групна идентификација. Свеста на поединецот за припадност не се создава благодарејќи на изолираноста, туку пред сѐ со меѓусебно спротивставување на разликите што ги истакнуваат луѓето за да ги утврдат културните граници. Се поставува прашањето: како да ја согледаме „различноста“ - од позитивна или од помалку позитивна страна? Во првиот случај идентитетот се темели на позитивното сознание (признавање) на другиот - што доведува до солидарност и вклучување, а во другиот на негација на различноста - што доведува до исклучување. Затоа, суштината на мултикултурализмот како процес постојано е во позиција на преиспитување и редефинирање, постојано на крстопат, поставувајќи го прашањето: Што Е? И што би требало ДА БИДЕ? (Kivisto, 2002, 3, 4). Ова се особено важни прашања од чиј одговор зависи (не)успешноста во справувањето со културните различности.

Дефинирањето на поимот култура секако би можело да помогне во дефинирањето на поимот културен идентитет, кој, од своја страна, пак, би можел попрецизно да го определи поимот културна заедница, што на крајот би помогнало во објаснувањето, дефинирањето и поимањето на специфичните, засебни културни заедници. Самата култура, која е менлива, истовремено ја чинат утврдени обрасци на однесување, дефинирани како структура или модел. Културата ја одредуваат: јазикот, симболите, вредностите, верувањата, нормите, обичаите и правилата на однесување. Бидејќи народите, како етнички групи, по некои од тие елементи помалку или повеќе се разликуваат едни од други, често културниот идентитет не може да се разграничи од етничкиот и се поистоветува со него (Božilović, 2006, 243). Денешните современи општества се повеќекултурни, а во стварноста, сите култури се хетерогени. Културниот идентитет истовремено е и состојба и процес, а е одреден со припадноста кон некаков начин, модел на манифестна практика, видлива или помалку видлива. Неспорно е дека културниот идентитет е еден од идентитетите што нѐ одредува, и во голем степен го 
условува нашиот начин на живот иако за него, во таа смисла, понекогаш помалку се зборува отколку за: полниот, родниот, семејниот, националниот или професионалниот идентитет (Mićunović, 1997, 147). За функционирањето на денешните мултикултурни општества, културата е важна и поради степенот на менливост бидејќи силата на културата не е само во нејзината посебност и чистота, туку и во начинот на изнаоѓањето сила за да се трансформира (Habermas, 1994, 118). Сепак, за тоа е потребна голема посветеност на денешните општества, на државните политики и во глобални рамки. Се поставува прашање: колку од државите се подготвени да вложуваат во таквите промени?, а најкомплексното прашање во тесна врска со тоа е: како донесените правно-политички мерки да се спроведат во пракса?

Етницитетот сфатен како ориентација кон националното потекло, религијата или јазикот, последниве години се засилува на интензитет. Истовремено може да се разгледува како универзален општествен феномен, но и како современа културна конструкција. Може да биде замислен, како своевиден тип на неформална политичка организација, или како функционален граничен механизам со кој се раздвојуваат ендогамните групи (Барт) (Eriksen, 2019, 35). Како стратегиски концепт во антрополошките теориски размислувања, користејќи неколку главни концептуални пристапи (примордијалниот, инструменталниот и конструктивниот пристап) теориите на етницитетот настојуваат да ги објаснат феномените на општественото и социјалното живеење: формирање на идентитетите, создавање на нациите, општествените промени, интеретничките односи, асимилацијата, акултурацијата, конфликтите во општеството и слично. Од своја страна, етницитетот е моќен образец во комплексот на: чувствата, мислењата и однесувањата. Во обидот за дефинирање, теоријата на етницитетот постојано се среќава со прашања од обемот на категоријално атрибуирање со кое учесниците себеси се идентификуваат и се идентификувани од страна на другите, со проблемот на границата на одредена група, кои служат како основа за дихотомизација „ние - тие“ и со проблемот на фиксирање на идентитетските симболи на кои е засновано верувањето за заедничкото потекло.

Според Валерштајн, припадноста кон некоја етничка заедница е предмет на социјално дефинирање, на интеракцијата меѓу самодефинирањето на членовите и дефинирањето што го прават другите заедници. Токму тој дијалектички однос меѓу егзогените и ендогените дефиниции на етничката припадност го прави етницитетот динамички процес, кој секогаш е подложен на редефинирање и прекомпонирање (Putinja; Žoslin, 1997, 160). Егзогената дефиниција ги покрива сите процеси на етикетирања и означувања, кои на една заедница, ѝ се припишуваат однадвор. Кога се служиме само со таа дефиниција, таа ни укажува на ситуација во која одреден идентитет станува атрибуиран со колективи „на кои во исто време им се одзема правото самите себеси да се дефинираат“" (Wallerstein, 1988, според Putinja; Žoslin, 1997, 160). Наместо „статичното“ подразбирање на етницитетот Барт нуди „динамичко“ поимање на етницитетот (конструктивен пристап), што подразбира менливост на етничкиот идентитет. Според Барт, етницитетот произлегува од акциите и 
реакциите меѓу етничките групи внатре во општествената организација, која непрестајно се развива. Тоа значи дека етничкиот идентитет се формира и се менува низ интеракцијата меѓу етносите, а се должи благодарејќи на процесите на вклучување и исклучување, кои ја воспоставуваат границата меѓу етничките групи. Барт истакнува дека во рамките на ваквите процеси на социјална организација, со кои трајно се одржуваат дистинкциите меѓу различните етноси, „културните црти“ што се земаат предвид, не претставуваат збир на „објективни“ разлики, туку се земаат предвид само оние што, самите актери, ги сметаат за важни. Најпосле, основното тежиште на теориските размислувања на Барт се однесува на етничката граница како разграничување меѓу заедниците, но не од природен, географски тип, туку како промислување за општествените граници, иако тие истовремено можат да се поклопуваат со територијалните граници (Барт, 2007, 77).

Културата, сфатена во најширока смисла на зборот, претставува клучен фактор за анализа на културните идентитети, кои се подложни на разни влијанија однадвор и одвнатре. Иако, според Тејлор, културата е белег на сите човечки општества, секое со свои посебности, и е карактеристика и на „локалното“ и на „поединечното“ живеење (Čačić-Kumpes, 2004, 146), сепак, „ограничувањето во локални рамки понекогаш е апстракција бидејки нема чиста локална култура или култура на некоја посебна општествена група (национална или етничка)“ (Čačić-Kumpes, Heršak, 1994, 192).

Како форма на политичко управување, првичното официјално применување на мултикултурализмот се случи во Канада во 70-тите години на XX век, како реакција на засилувањето на сепаратизмот и барањата за остварување на права меѓу канадските Французи од Квебек. Тогашниот канадски премиер за прв пат го употреби терминот мултикултура сакајќи да ја промовира еднаквоста, толеранцијата и инклузијата на малцинските и културните заедници во Канада (Ang, 2005, 226, 228). Терминот подоцна беше вклучен и во Меѓународната енциклопедија на општествените и на бихејвиоралните науки, второ издание од 2015 година, каде што се однесуваше и на имигрантите (Eriksen, 2015, 28, 29).

Други земји, кои исто така порано почнаа да експериментираат со мултикултурната политика беа: САД, Велика Британија, Германија и Австралија. Како по некое правило, земјите со значителна етничка и културна разновидност би требало полесно да ги прифаќаат мултикултурните политики бидејќи плурализмот е дел од нивната секојдневна политичка стварност, но денес сме сведоци дека не е така секогаш. Новата левица, која се разви од 70тите години на минатиот век, изнаоѓаше различни форми на практики, мобилизирајќи се врз основа на различни видови „политика на идентитет“, поврзани со барањата за признавање и правичност меѓу, на пример, локалните староседелци, различните имигрантски и етнички малцинства, барањата на разни здруженија на жени и други маргинализирани групи, кои постојат во општеството. Со прифаќањето на мултикултурализмот, тогашната политичка левица го направи она што може да се окарактеризира како „културно 
значење“, кое придонесе за „културализација на политиката“, што ги одбележа последните децении од минатиот век (Žižek, 2008, 264). Како последица на тоа, културата, вклучително и религијата, стануваат сѐ поважна рамка за разбирање на современиот политички и општествен развој - иако може да се каже дека мултикултурализмот се менува на повеќе начини и е сложен во повеќето земји.

Сѐ до деведесеттите години на минатиот век мултикултурализмот (разбран како процес) имаше важна улога во развојот на правото и на политиката за (во почетокот на дваесет и првиот век во многу земји мултикултурализмот како идеологија) да започне сѐ повеќе да се преиспитува, да се критикува и да доживува различни форми на политички притисоци. Основната забелешка се состои, главно, во убедувањата на поодделни структури дека и покрај сета државна поддршка, која ја доби, тој и понатаму отвора можности за создавање на т.н. паралелни општества. На сметка на тоа, континуирано слабеат заложбите на државите за заедничките колективни вредности во општеството, кои треба да се реализираат преку осмислени практики за заеднички вредности.

Терминот мултикултурализам разбран дескриптивно, културолошки и правно-политички, балансирајќи меѓу: политиката, културата, правните регулативи, медиумската фела и академските толкувања, е нешто што, како идеологија, тешко може да се разбере и да се објасни на едноставен и унифициран, прифатлив начин. Најголемиот дел од теоретичарите, коишто се занимаваат со мултикултурализмот се среќаваат со прашања, кои укажуваат на тоа дека се работи за исклучително сложен и повеќеслоен феномен, кој е тешко теориски, методолошки и концептуално да се разграничи и да се дефинира (Башић, 2006, 53). Она што е заедничко за поимот е неговата основна прифатена поставеност како збир на активности и практики, присутни во: етнички, религиски и културно комплексни општества, во кои, преку различни политики се настојува да се создадат услови за еднаквост меѓу граѓаните што живеат во тие општества. Односот меѓу антропологијата и мултикултурализмот не е далечен иако е видливо несогласувањето околу одредени разбирања и практики, бидејќи концептуализацијата на културните идентитети од една страна и границите што се претпоставени во мултикултурализмот, од друга страна, произлегуваат од антропологијата како теорија и особено од начините на кои се манифестира мултикултуралноста и различните општества во смисла на нивниот степен на развиток. Не може, во секое општество, со исти механизми да се мотивира, да се храни, да се манифестира или да се поддржува мултикултурата. Антрополошките текстови се однесуваат на спроведени истражувања на мултикултурни пристапи од студии за локални меѓуплеменски судири, училишни наставни програми, преку секојдневниот космополитизам во некои општества, до ксенофобијата во Европа. Како емпирија се разбира дека тие некаде постојат, но како аналитички концепт, одредени автори го сметаат за дискутабилен (Eriksen, $2015,29)$. Иако различностите на сите нивоа се присутни исто толку колку и во самото човештво, сепак, во денешен контекст, овој поим се однесува на современите општества во кои соодветните дискурси и политики, пред сѐ, се 
фокусираат на создавање групни културни права. Во терминолошка смисла, исто така, не е едноставно да се определи неговата суштина. Дека се работи за релативно нова кованица, следствено на тоа и за регулирана осмислена практика, може да се види доколку се побара во некои од речниците. Во речникот на странски зборови и изрази на Вујаклија, кој за прв пат е издаден во 1937 година, терминот не е забележан, но постојат термините мултидисциплинарен и мултинационална - што се однесува за компанија (Вујаклија, 1996/97, 571). Во речникот на правни термини на српско-англискофранцуски од 2002 година, исто така не постои, меѓутоа постојат термините мултинационален и мултилатерален (Jovanović; Todorović, 2002, 131, 965). Во илустрираниот оксфордски речник на англиски јазик од 1998 година, во македонското второ издание од 2004 година, забележан е терминот multicultural и од него изведените форми multiculturalism, multiculturalist $u$ multiculturally (Илустриран Оксфорд речник на англискиот јазик, 535). Сепак, во изданието на овој речник, објавен во Швајцарија во 1957 година, се вели: „карактеристики на мултикултурното општество се (исто така) политиката или процесот, преку кој се одржуваат или поддржуваат различните идентитети на културните групи во таквото општество“ (Eriksen, 2015, 29), што значи дека и во тие години биле познати улогата и елементите на мултикултурата. Но, денес, во контекст на мултикултурноста во простор и во време, како никогаш досега, се видливи различните традиции и различните вредносни системи, кои често видливо го покажуваат своето меѓусебно несогласување.

Во теоријата, но и во практиката на мултикултурноста особено се прави разлика меѓу дескриптивните и нормативните аспекти на мултикултурализмот. Вообичаената описна дефиниција на мултикултурноста се однесува на начините на прифаќње и однесување, кои ги создаваат државите за справување со различните културни вредности, практикувани од заедниците што живеат во заедничко општество, преку конструирање на соодветни механизми. Во пракса, практикувањето на мултикултурноста треба да обезбеди, да создаде подеднакви можности за поинаквиот од нас во делот на културната различност „во атмосфера на меѓусебна толеранција“ (Majnhof; Triandafilidu, 2008, 14). Познавањето и признавањето на културната различност во содејство со соодветните мерки, кои се преземаат од државно ниво, би требало да го зајакнат живеењето во мултикултурното општество иако овде спаѓаат многу различности за кои најчесто нема подеднаков степен на разбирливост ни кај мнозинскиот народ ни кај различниот од него. Во многу од реалните денешни примери различноста не е насекаде иста, односно таа не вклучува исти или приближно слични: историски, културолошки, миграциски движења на просторно блиски/далечни територии, еднаквости или барем сличности. Некаде, дури законите во државите можат да бидат такви што на малцинските заедници им овозможуваат привилегиран статус, посебни олеснувања, кои понекогаш водат до право на политичка автономија (Semprini, 1999, 44). Во Македонија, на пример, владата како форма на решавање на интеретничкиот судир со албанската етничка заедница, како најбројна во Македонија, спроведува политика на имплементација на 
мултикултурално вклучување, предложена (во многу сегменти и контролирана) од меѓународната заедница. Преку политиката на признавање, Владата се обидува да постигне општествено ангажирање на малцинските барања од сите етнички заедници, обезбедувајќи промовирање на јазичните и на културните различности (Станковић Пејновић, 2016, 356) со широко признати права.

Со оглед на фактот дека мултикултуралноста го поставува прашањето за идентитетот и неговото признавање, вообичаена рамка на мултикултурните расправи е поврзана со: малцинствата, етничките заедници и општествените движења и промени. Несомнено дека првично односот кон различностите, од страна на државните власти, биле позитивистички. Во Европа, различниот културолошки дискурс се јавил по шеесеттите години на минатиот век во Велика Британија кога се вовеле практични политики за намалување на расната дискриминација во контекст на општествената и социјалната интеграција на етничките малцинства. Во практиката, тоа значело преземање на активности преку кои владите протежирале: чувство на солидарност, разбирање и прифаќање на другите култури, поттикнување на дијалог со различните етнички групи, забрана на дискриминација и форсирање на еднакви права на малцинските заедници. Вака напишани, во многу ставки потсетуваат на југословенскиот социјалистички период (Мирчевска, 2020, 28, 30). Но, познато е како заврши тој.

Се промовираат различни „мултикултурализми“, што е главна причина поради што во критичките погледи на мултикултурализмот е присутна видливата настојчивост да се потенцира големата релативистичка толеранција на обичаите и верувањата на „другите“ или пак на некритичката поддршка на секаков вид имиграција во некоја од земјите, каде што на имигрантите им се овозможени многу права, а им се даваат малку обврски. Затоа, денес можеби и не се зачудувачки реакциите на властите во некои ситуации кога трпението, или подобро речено толеранцијата, на граѓаните, кои се носители на етничкиот мнозински елемент, ќе ослаби. Во оваа насока, прашањето за мултикултурноста во развиените западни општества (држави) стана мошне актуелно во последниве две децении. Генерално се смени позитивистичкиот поглед кон културните различности и конструираниот политички однос и пристап кон мултикултурализмот, кој наеднаш стана своевидна пречка и предизвик за современите држави, за што, во моментов, немаат прифатливо решение. Ако првично, противењето на мултикултурализмот како идеологија се сметаше за став близок до расистичкото или фашистичко гледиште, во најмала рака како недостаток на чувство за човечност (Milenković, 2014, 260), денес по две-три децении се соочуваме со неуспешноста на овој проект. Станува збор за негативните последици, кои се јавија и кои, во јавниот дискурс, предизвикаа директни и недвосмислени изјави за потполниот неуспех на начините на кои општествата се справуваа(т) со различностите. Ова е констатирано од највисоките влијателни лица на европската политичка сцена, пред сѐ, почнувајќ́ од германската канцеларка Ангела Меркел, која јавно, од толку висока државничка позиција, изјави дека муликултурниот живот во Германија е сосема пропаднат и дека создадената визија за можен 
заеднички живот на различните култури била само привидна (октомври 2010). Осврнувајќи се на привремено вработените странци, познати како гастарбајтери (Gastarbeiter) (термин познат и одомаќен и во југословенското општество за вработените Југословени во Германија од шеесеттите и седумдесеттите години на минатиот век), истакна дека се надевале на нивно заминување по одредено време, но тоа не се случило. На истата конференција, десничарските партии се определуваат да ѝ дадат поддршка на доминантната германска култура, нагласувајќи дека нема да им се дава поддршка на оние што живеат од државна социјална помош, што користат државно осигурување, што не ги праќаат децата на училиште и што ги држат младите девојчиња забулени. Генералната порака, која ја соопшти најпосле канцеларката Меркел беше дека Германија треба да ги заостри критериумите кон оние што не сакаат да се интегрираат во германското општество, пред да ги прифатат следните генерации на мигранти (Guardian, 17. окт 2010). Уште појасна беше изјавата на тогашниот претседател на Франција, Никола Саркози, во февруари 2011, кој се почувствувал загрозен од посветеноста на француската држава за другиот/другите, со што сметал дека францускиот идентитет е загрозен, велејќ́: „... премногу бевме фокусирани на идентитетот на лицата кои доаѓаат, а недоволно на идентитетот на државата која ги прими“ (The Telegraph, 11. фев. 2011). Ништо поразличен не е ниту ставот на Дејвид Камерон, кој најави дека планира да спроведе радикална промена на досегашната практика на мултикултуралната стратегија, која ја спроведуваа претходните влади, планирајќи да усвои нов активен, цврст либерализам и да се применуваат закони, вредносни правила и слобода на говор, еднакви за сите во Велика Британија. Зборувајќи за терористичките напади во Лондон во 2005 година, и потенцирајќ́ дека новата политика ќе презема и засилени антитерористички мерки, сосема е јасно дека овие активности се насочени првенствено кон муслиманската популација во Британија (Barrett, 2013, 21). Но, не е случајност што фокусот на Камерон е ставен на религиозно различниот од мнозинската религија во државата. Во етничките процеси не се непознати примерите кога религискиот идентитет се изедначува со етничкиот (Мирчевска, 2015, 208), а во британското општество, со новите муслимански генерации, се случува токму тоа, а идентификација врз религиска основа станува примарна (Башић, 2016, 53).

Што придонесе за ваквиот однос на европските држави, кој се смени во драстична спротивност?

Најпрво долгогодишната мигрантска криза предизвика дискусии во државите членки на Унијата што станаа свесни за сопствениот национален идентитет, кој доживува своевидна ревитализација и зајакнување. Во теоријата постојат различни елементи, кои влијаат врз зајакнувањето на идентитетот, но и такви, кои влијаат на слабеење на идентитетот. Во првите спаѓаат миграциите - најчесто оние што настанаа како резултат на војните, кои резултираа со голем број бегалци и азиланти и кои, меѓу Европејците, ги иницираа свеста и зајакнувањето на чувството на припадност кон својот идентитет, а меѓу оние што го слабеат идентитетот е глобализацијата, но и 
заедничката правна регулатива на Европската Унија, која, на што сме сведоци и ние, не им одговара секогаш на сите членки на заедницата.

Мултикултурноста, исто така, спаѓа во елементите што го слабеат националниот идентитет. Континуираниот наплив на информации, глобалниот притисок и различните глобални барања, масовната комуникација како резултат на развиеноста на технологиите, придонесоа релативно поедноставен пристап до различни културни вредности, кои, пред триесетина години, не биле присутни. Денес глобализацијата е еден од најактуелните општествени процеси, кои проникнуваат во сите сегменти на човековото живеење. Одеднаш нешто за што не сте знаеле, нешто за што во сопствената култура веќе сте имале етаблиран начин на манифестирање и прифаќање, влегува во вашиот живот и носи практики, кои дотогаш не ви биле познати, ниту пак блиски. Бројни се примерите на оваа појава, особено на празнувањата за кои: локалната, националната, религиската практика нема соодветна културноисториска поврзаност ${ }^{1}$. Така, процесот на глобализација донесе нови општествени форми и принципи, со што се формира глобална култура, преку: здруженија, фондови, заедници од светски карактер, каде што не е важен националниот идентитет на членките. Како резултат на ваквата состојба, сосема е реално кога Семприни, мултикултурализмот го нарекува дете на кризата на модернизмот (Semprini, 1999, 134). Меѓу сето ова е видлива примарната улога на финансиите и капиталот пред сѐ. На тој начин се засилува криза на идентитетот, создавајќи потреба од негово редефинирање. Некои од критичарите на мултикултурализмот, како концепт, меѓу другите забелешки, сметаат дека муликултурализмот како начин на справување ги стигматизира и ги гетоизира различните, и така ги спречува да се интегрираат во општеството (Kimlicka, 2003, 18, 19).

Денес, речиси стана експлицитно, секојдневно препознатливо, дека мултикултурализмот замижува пред создадените проблеми до степен на непрепознавање, а преку некои од своите решенија и практики ја поттикнува и стимулира сегрегацијата на културата, дава можности за создавање на двојни општествени вредности и создавање на паралелни општества во државите и можеби најважно - ја оневозможува конструктивната дебата преку „тиранијата на политичката коректност“ (Milenković, 2014, 9, 10), која во многу случаи се злоупотребува. Во ваква реалност, беше само прашање на време кога европските општества ќ изреагираат со спротивставени тези за мултикултурното општество, кои засега се само вербални. Можеби беше потребен само посилен и подолготраен имигрантски притисок.

1 Тука, пред сѐ, станува збор за прифаќање на подалечни и поблиски културни вредности, како што се обичајните практики својствени за други културни средини (Хелоувин - Ноќ на вештерките (Halloween), Валентајн - денот на вљубените (Saint Valentine's Day), употреба на предмети, кои се поврзани со други културни, религиски невербални елементи (на пример за Велигден) и слично. 


\section{ЛИТЕРАТУРА}

\section{Кирилични изданија}

БАШИЋ, Г. (2006). Принципи либерализма и комунитаризма у организацији мултиетничких постсоцијалистичких друштва. Свакодневна култура $у$ постсоиијалистичком периоду, 22, Београд: Етнографски институт САНУ, 5173.

БАШИЋ, Г. (2016). Етнокултурни идентитети - политике признања и праксе опстанка. Стање и перспективе мултикултурализма у Србији и државама региона, Стање и перспективе мултикултурализма у Србији и државама региона. књ. CLXV, књ. 38, 51-63, Београд: САНУ.

ВУЈАКЛИЈА, М. (1996/97). Лексикон страних речи и израза, јубиларно издање, Просвета, Београд.

ГОЛУБОВИЋ, 3. (2005). Мултикултурализам као облик демократске државе. Изазови демократије у савременом друштву, Браничево, Пожаревац.

МИРЧЕВСКА, М. (2007). Вербални и невербални етнички симболи во Горна Река. Скопје: Институт за етнологија и антропологија, посебни изданија, кн.2.

МИРЧЕВСКА, М. (2015). Улогата на религијата во јавниот дискурс при конструирање на етничкиот идентитет: современи македонски случувања. Македонщите со исламска религија во историски и современ контекст. Скопје: МАНУ, 201-215.

МИРЧЕВСКА, М. (2020). На тема мултикултура: Антропологија на заедништвото или како братството и единството се претвори во соживот. Етнолог, бр. 19, 23-39.

ПАВЛОВИЋ, М. (1998). Срби у Чикагу - проблеми етничког идентитета, Етнографски Институт САНУ, Београд.

СТАНКОВИЋ ПЕЈНОВИЋ, В. (2016). Амбивалентност мултикултурализма у Македонији. Стање и перспективе мултикултурализма у Србији и државама региона. књ. CLXV, књ.38, Београд: САHУ, 355-373.

ФРИДРИХ, Б. (2007). Етничките групи и нивните граници. Теории на другоста. Скопје: ЕвроБалкан Прес, 69-107.

\section{Латинични изданија}

ANG, I. (2005). Multiculturalism. New Keywords: A Revised Vocabulatory of Culture and Society. MA: Blackwell, 34-37.

BARETT, M. (2013). Introduction - Interculturalism and multiculturalism: concepts and controversies. Interculturalism and multiculturalism: similarities and differences. Edited by Martyn Barrett, Council of Europe, 15-41.

BAŠIĊ, G. (2007). Politika multikulturalnosti, zaštita ili kontrola etničkih identiteta?, Filozofija i društvo, br. 3, 167-195.

BOŽILOVIĆ, N. (2006). Identitet i znacenje stila u potkulturi. Filozofija i drustvo, 2, 233-250. 
ČAČIĆ-KUMPES, J. (2004). Politike reguliranja kulturne i etničke različitosti: o pojmovima i njhovoj upotrebi. Migracijske i etničke teme, 20, 143-159.

ČAČIĆ-KUMPES, J. HERŠAK, E. (1994). Neki modeli uređivanja etničkih i kulturnih odnosa u višeetničkim i višekulturnim društvima. Migracijske teme, br. 34, god. 10, 191-199.

ERIKSEN, T. H. (2015). Multiculturalism, Anthropology of. International Encyclopedia of the Social \& Behavioral Sciences, Second Edition, Volume 16, 2833.

ERIKSEN, T. H. (2019). The epistemological status of the concept of ethnicity. Anthropological Notebooks, XXV/1, 27-36.

GOLUBOVIĆ, Z. (1997). Antropologija u personalističkom ključu. BeogradValjevo: Gutenbergova galaksija.

HABERMAS, J. (1994). Strugles for recognition in the Democratic Constitutional state. Multiculturalism: Examming the politics of Recognition. Princeton University Press, 107-148.

JOVANOVIĆ, J., Todorović, S. (2002). Rečnik pravnih termina, srpsko-engleskofrancuski. Beograd: Savremena administracija.

KIVISTO, P. (2002). Multiculturalism in a Global Society. Oxford: Blackwell Publishing.

KYMLICA, W. (2003). Multikulturalno građanstvo - liberalna teorija manjinskih prava. Zagreb: Naklada Jesenski i Turk.

MAJNHOF, U. H. Triandafilidu, A. (2008). Transkulturna Evropa - Kulturna politika u Evropi koja se menja. Beograd: Clio.

MIĆUNOVIĆ, N. (1997). Kulturni identitet na prostoru bivše Jugoslavije. Filozofija i društvo. God. XII, 147-157.

MILENKOVIĆ, M. (2008). Problemi konstitucionalizacije multikulturalizma pogled iz antropologije. Etnoantropološki problemi, 2 (3), 45-57.

MILENKOVIĆ, M. (2014). Antropologija multikulturalizma, Od politike identiteta ka očuvanju kulturnog nasleđa. Beograd: Filozofski fakultet, Srpski geneološki centar.

PUTINJA, F. Zoslin S. F. (1997). Teorije o etnicitetu. Beograd: Biblioteka XX vek. SEMPRINI, A. (1999). Multikulturalizam. Beograd: Clio.

ŽIŽEK, S. (2008). In defense of lost causes. London-New York: Verso.

\section{Сајтографија}

http://dx.doi.org/10.1016/B978-0-08-097086-8.12113-0 (посетено: 08.12.2019) http://www.telegraph.co.uk./news/worldnews/europe/france/8317497/NicolasSarkozy-declares-multiculturalism-had-failed.html (посетено: 08.12.2019). http://www.securityconference.de/Cameron-David.634.0.html?\&L=1 (посетено: 08.12.2019)

http://www.sqild.se/Content/106426/Interculturalism-vs-Multiculturalism.pdf (посетено: 08.12.2019)

https://www.academia.edu/24749771/Multiculturalism_Anthropology_of (посетено: 08.12.2019) 
www.guardian.co.uk/world/2010/oct/17/angela-merkel-germany-multiculturalismfailures (посетено: 08.12.2019)

Mirjana P. Mirchevska

\section{ANTHROPOLOGY OF MULTICULTURALISM: THEORY AND PRACTICE}

Summary

The topic of the paper is multiculturalism as a theoretical anthropological issue, which in recent decades has been paid particular attention by the social sciences and humanities. The paper deals with the development of the basic postulates of multiculturalism, which has been created for several decades, and finally undergoes radical changes in its development. The interest has been sparked primarily by public statements by European leaders about the failure of this concept, which has existed for decades, to integrate primarily immigrant ethnic communities into existing liberal democracies. The ways in which an ethnic community that has cultural characteristics different from those in the countries where it seeks to be incorporated, can be manifested through segregation, assimilation, acculturation, but also by recognizing and respecting the identity particularities of the various ethnic and cultural communities. Multiculturalism as a practice commonly referred to as synonymous with cultural pluralism analyzed by way of the multicultural reality, but also for multiculturalism as a theory and response to this reality that many years creates mechanisms that are trying to make a successful project.

Today it is becoming increasingly apparent that multiculturalism 'closes its eyes' to the problems created and through some of its solutions and practices promotes and stimulates cultural segregation, provides opportunities for the creation of dual societal values and the creation of parallel societies in states and perhaps most importantly - disables constructive debate through the pressure for so-called "political correctness". In such a real situation, it was only a matter of time before European societies would react with opposing theses of a multicultural society, which for now, are only verbal. 